\title{
Effect of levels organic fertilizers and kinds of Bio-feritilizers in characterical of two classes of Okra plant (Abelmoschus esculentus L.) growning in the plastic house.
}

\author{
${ }^{1}$ Riam A. Jabbar,${ }^{2}$ Razzaq A.Suqer, ${ }^{3}$ Razzaq G. Neghamish, ${ }^{4}$ Ahmed Salam Jwar \\ ${ }^{1,2,3,4}$ University of Thi-Qar, College of Agriculture and Marshlands, Department of Horticulture and Landscape
}

\begin{abstract}
:
The experiment was carried out for the agricultural season 2020-2021 under unheated greenhouse conditions at the Agricultural Research Station of the Department of Horticulture and Garden Engineering / College of Agriculture University of Dhi Qar, studying the effect of levels of organic and biological fertilizers on the growth and yield of two okra varieties (Al-Hussainawi, Petra). The experiment was carried out with three factors: the first cultivar includes two okra cultivars (Al-Hussainawi A, Petra B), the second sheep manure with four levels $\mathrm{O}_{0}$ without addition, $\mathrm{O}_{1}\left(2.5 \mathrm{~kg}\right.$ experimental unit), $\mathrm{O}_{2}\left(5 \mathrm{~kg}\right.$ experimental unit) and $\mathrm{O}_{3}(7.5 \mathrm{~kg}$ experimental unit) and the third is a mixture of bio-fertilizer And at four levels: $\mathrm{O}_{0}$ without addition, $\mathrm{A}($ Azo.) (Azotobacter chroococcum): at a concentration of $1.1 \times 10^{9}, \mathrm{~B}$ (Pseu.): (Pseudomonas flourescens) at a concentration of $3.6 \times 10^{9}$ and $\mathrm{C}($ Azo. + Pse.): (Azotobacter chroococcum + Pseudomonas flourescens) at a concentration. $4.7 \times 10^{9}$ The arithmetic averages were compared according to the LSD Least Significant Difference test at a probability level of 0.05 . The results can be summarized as follows: It showed the superiority of the Husseinawi okra variety over the Petra okra variety in the leaf content of carbohydrates and phenols in the fruits, which amounted to $\left(12.448 \mathrm{mg} 100 \mathrm{gm}^{-1}, 2.132 \%\right)$. ) respectively. While the Petra cultivar was superior in the content of leaves of chlorophyll and a decrease in the content of the leaves of carotene and proline, it reached $\left(69.615 \mathrm{mg} 100 \mathrm{gm}^{-1}, 1.882 \mathrm{mg} 100 \mathrm{gm}^{-1}, 190.0\right.$ microgram $\left.\mathrm{g}^{-1}\right)$. With regard to the organic fertilizer, the treatment $\mathrm{O}_{3}(7.5 \mathrm{~kg}$ experimental unit) for Al-Hussainawi variety was superior in the content of leaves of chlorophyll and phenols in the fruits, it amounted to $\left(74,729 \mathrm{mg} 100 \mathrm{gm}^{-1}, 2.742\right.$ $\%$ ), while the Petra variety excelled in the content of carbohydrates and the low content of the leaves of carotene and proline. It reached (14,394 mg $\left.100 \mathrm{~g} \mathrm{~g}^{-1}, 0.951 \mathrm{mg} 100 \mathrm{~g}^{-1}, 142.9 \mathrm{mcg} \mathrm{g}^{-1}\right)$ respectively. As for the biofertilizer, the treatment $\mathrm{C}($ Azo. + Pse.) was superior in the leaves content of chlorophyll and carbohydrates, and the leaves content of carotene, proline and phenols in the fruits was $\left(72,555 \mathrm{mg} 100 \mathrm{~g}^{-1}, 13.683 \mathrm{mg} 100 \mathrm{~g}-1,0.974 \mathrm{mg} 100 \mathrm{~g} \mathrm{~g}^{-1}, 156.7\right.$ micrograms $\left.\mathrm{g}^{-1}, 2.534 \%\right)$ respectively. As for the effect of the bilateral interaction between okra cultivars and biofertilizer types, the $\mathrm{BC}(A z o .+P s e$.) treatment was superior to the chlorophyll content of leaves and the decrease in the leaves' content of carotene and proline, it amounted to $\left(72,996 \mathrm{mg} 100 \mathrm{~g}^{-1}, 0.762 \mathrm{mg} 100 \mathrm{~g}^{-1}, 136.2\right.$ micrograms $\left.\mathrm{g}^{-1}\right)$, while the $\mathrm{AC}($ Azo. + Pse. $)$ treatment excelled in the leaves content of carbohydrates and phenols in fruits, it reached $\left(13.878 \mathrm{mg} / 100 \mathrm{gm}^{-1}, 2.576 \%\right)$, respectively. The bilateral interaction between organic and biofertilizers showed the superiority of $\mathrm{O}_{3} \mathrm{C}(A z o .+P s e$.) treatment in the leaves content of chlorophyll and
\end{abstract}


carbohydrates, and the decrease in the leaves' content in carotene, proline and phenols in fruits, it amounted to (77,065 mg $100 \mathrm{~g}^{-1}, 15.722 \mathrm{mg} 100 \mathrm{~g} \mathrm{~g}^{-1}, 0.297 \mathrm{mg}\left(100 \mathrm{gm}^{-1}, 121.6 \mathrm{mcg} \mathrm{g}^{-1}, 3.4088 \%\right)$ respectively. The triple interactions showed a significant effect on most of the studied traits.

\section{INTRODUCTION}

Okra crop, scientific name Abelmoschus esculentus L., is one of the important summer vegetable crops in Iraq, which grows in all agricultural areas belonging to the family Malvaceae (Boras et al., 2011). Okra is called by other names such as Ladies Finers, Bamya, Gumbo, Okura, Kacang Bendi And other designations in relation to the countries in which it is located (D.Sathish et al., 2013) Okra is grown in the regions of Iraq for the purpose of obtaining its fresh green fruits, and provides humans with proteins, vitamins (K, E, C, B, A), carbohydrates and minerals (Abd EI-Kader et al., 2010).Researchers and specialists worked to increase the agricultural area in vegetable crops and to devise new varieties and hybrids with good fruit and vegetable traits and high productivity, and the introduction of hybrids is considered one of the cheapest methods of breeding and genetic improvement in countries, especially developing countries, to obtain good genetic results and select genetic structures. Through the Center for Scientific Research and knowledge of the most appropriate environmental conditions (Al-Shammari and Saud, 2014) The large population in the world requires an increase in the production of multiple agricultural crops inside greenhouses (glass and plastic) without Its season is in addition to open cultivation. The use of organic fertilizers will be an inevitable practice in organic agriculture to meet the plant's need of nutrients necessary for growth, and organic fertilizers are interventions that increase production and improve the quality of crops by preparing elements and improving the course of vital activities in plants (Verma et al., 2017), as well as the use of fertilizers The vitality and activity of microorganisms in the soil is considered an appropriate source for providing the necessary elements for plants, as compared to chemical fertilizers (Al-Haddad, 1998). Recently, many countries have tended to encourage the biological production of plants that are characterized by clean food free of harmful effects resulting from chemical fertilizers (Al-Amri, 2011). The technique of using biological fertilizers in natural agriculture or modern agricultural technology (Bio. Farming) is one of the advanced technologies through the better use of biological and organic fertilizers, and the reduction of the addition of chemical fertilizers despite the cheapness and abundance compared to chemical fertilizers, in addition to improving the physical properties of soil Chemical, stimulating plant physiological functions, stimulating organic farming as fertilizer for many horticultural crops, increasing the readiness of basic nutrients NPK and micro-elements, fixing nitrogen in the soil and improving plant growth and production (Al-Jubouri, 2013). Given the great importance of adding organic fertilizers and types of biological fertilizers in reducing pollution, reducing economic damage, maintaining public health, increasing plant growth production and creating a clean healthy environment, so the research goal is to use such fertilizers and reduce chemical fertilizers and apply them to the two types of okra plant in Iraqi soils and homes. 


\section{MAERIALS AND WORKING METHODS}

The field experiment was conducted during the agricultural season (2020-2021) in one of the unheated greenhouses with dimensions of $51 \mathrm{~m} \mathrm{x} 9 \mathrm{~m}$ and an area of $459 \mathrm{~m} 2$ affiliated to the College of Agriculture and Marshlands Dhi Qar University, which is located in Al-Mustafaiya area, to study the effect of levels of organic fertilizer and types of biofertilizer of the two okra plant varieties. In some physical and chemical characteristics of okra plants inside greenhouses, random samples were taken before planting from different places of the soil of the greenhouse with a depth of 0-30 cm, mixed well, and then their physical and chemical properties were analyzed in the soil laboratory of the College of Agriculture.

Table (1): Physical and chemAnalysis type Unit of measure Value

\begin{tabular}{|c|c|c|}
\hline Analysis type & Measruing unit & The value \\
\hline $\mathrm{Ec}$ & $\mathrm{ds} \mathrm{m}^{-1}$ & 5.08 \\
\hline $\mathrm{pH}$ & ---- & 7.04 \\
\hline $\mathrm{N}$ & $\mathrm{ppm}$ & 40 \\
\hline $\mathrm{P}$ & $\mathrm{ppm}$ & 280.0 \\
\hline $\mathrm{K}$ & $\mathrm{ppm}$ & 22.06 \\
\hline The sand & $\mathrm{g} \mathrm{kg}^{-1}$ & 261 \\
\hline The greedy & $\mathrm{g} \mathrm{kg}^{-1}$ & 590 \\
\hline Mud & $\mathrm{g} \mathrm{kg}^{-1}$ & 149 \\
\hline Organic matter & $\%$ & 0.87 \\
\hline Soil texture & ---- & Sandy mixture \\
\hline
\end{tabular}

Laboratory of Soil Department at the Faculty of Agriculture - Dhi Qar University

Two types of local cultivars (Al-Hussainawy and Petra) were selected, desired by the consumer and known for their abundant production due to the large plants and many branches. They were planted directly in the ground after isolating the unwanted seeds in terms of shape and size. Then the seeds were soaked for 12 hours in lukewarm water before planting and then planted in A hollow at a depth of 3-4 cm, the distance between one hole and another is 30 $\mathrm{cm}$ on both sides of the meadow. The decomposed organic fertilizer was obtained from sheep residues from the barns and was added at the beginning of the experiment. 


\section{A- Study factors}

The first factor: my variety of okra

A type of Husseinawi

B class Petra

The second factor: levels of organic fertilizer

$\mathrm{O}_{0}$ without adding fertilizer.

$\mathrm{O}_{1}$ organic fertilizer at a rate of $2.5 \mathrm{~kg}$. experimental unit.

$\mathrm{O}_{2}$ organic fertilizer at a rate of $5 \mathrm{~kg}$. experimental unit.

$\mathrm{O}_{3}$ organic fertilizer at a rate of $7.5 \mathrm{~kg}$. experimental unit.

The third factor: types of biological vaccine

$\mathrm{O}$ without addition

A vaccine for Azotobacter Chroococcum at a concentration of $1.1 \times 10^{9}$

B Vaccine for Pseudomonas fluorescens at a concentration of $3.6 \times 10^{9}$

C Azotobacter Chroococcum+ Pseudomonas fluorescens vaccine at a concentration of $4.7 \times 10^{9}$

The number of experimental units in each sector is 32 and the total number is 96 units.

Study Indications:

1- Chlorophyll content.

2- The carbohydrate content of the leaves.

3- Carotene content.

4- The content of the leaves of proline.

5- Phenols in fruits. 


\section{RESULTS AND DISCUSSION}

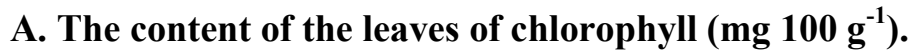

Table (2) shows that Petra okra cultivar B significantly outperformed Husseinawiya okra cultivar A, where the average leaf content of chlorophyll was $69.615,68,544 \mathrm{mg} 100 \mathrm{~g}-1$, respectively. 2009). The same table showed that adding different levels of organic fertilizer had a significant effect on the amount of chlorophyll at levels $2.5,5$,

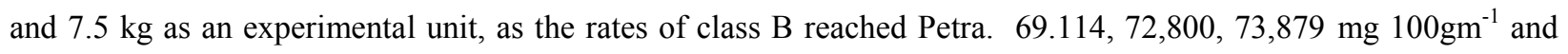

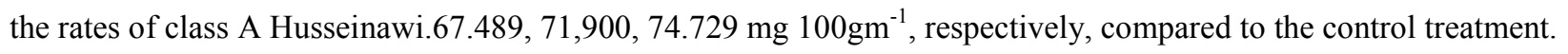
The content of chlorophyll increased with the increase in the level of addition, and the reason for this superiority is attributed to the positive effect of adding organic fertilizers that work to liberate Nitrogen in the soil and its large accumulation inside the plant, thus increasing the amount of chlorophyll in the leaves, as nitrogen enters the synthesis of chlorophyll through the construction of the porphyrins ring responsible for the formation of chlorophyll, and the amount of nitrogen in the leaf enters the composition of the chloroplast (Peter and Rosen, 2005). The same table also showed that the addition of types of biofertilizers had a significant effect, as it gave the rates of treatments (A, B, C) $67.798,69.823,72.555 \mathrm{mg} 100 \mathrm{~g}-1$ compared to without the addition, which amounted to $66,142 \mathrm{mg} 100$ $\mathrm{g}-1$, and the amount of chlorophyll increased in the treatments When diversifying in the addition of bio-fertilizer, the reason for this is the ability of microorganisms to fix atmospheric nitrogen, which helps to increase the rate of absorption by the plant, and it is noted that there is a positive relationship between the content of chlorophyll in leaves and nitrogen, as it enters into the composition of the molecule and this is consistent with what was reached (Farida et al. (2003) and Mostafa (2002) and Abu-Hussein et al. (2002) and Qurbanly et al. (2006). The table also showed that the binary interaction between the cultivars and the organic fertilizers had a significant effect, as the treatment $\mathrm{O}_{3}$ of the variety A gave the highest values amounted to $74.729 \mathrm{mg} 100 \mathrm{~g}^{-1}$, while the plants of the treatment $\mathrm{O}_{0}$ of the variety A gave the lowest values amounted to $60.058 \mathrm{mg} 100 \mathrm{gm}^{-1}$. The same table also shows that the bilateral interaction between cultivars and biofertilizers had a significant effect, as the treatment $\mathrm{BC}($ Azo. + Pse. $)$ gave the highest values amounted to $72,996 \mathrm{mg} 100 \mathrm{~g}^{-1}$, while the treatment plants $\mathrm{AO}_{0}$ gave the lowest values amounted to $65.410 \mathrm{mg} 100 \mathrm{~g}^{-1}$. The same table showed the bilateral interaction between organic and biofertilizers with a significant effect, as the treatment plants $\mathrm{O}_{3} \mathrm{C}($ Azo. + Pse. $)$ gave the highest values amounted to

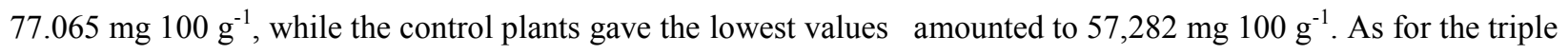
interaction between the experimental factors, it was significant, as the overlapping treatment $\mathrm{A}^{*} \mathrm{O}_{3}{ }^{*} \mathrm{C}($ Azo. + Pse. $)$ excelled in obtaining the highest values, reaching $77.745 \mathrm{mg} 100 \mathrm{gm}-1$, while the plants of the treatment $\mathrm{A}^{*} \mathrm{O}_{0} * \mathrm{O}_{0}$

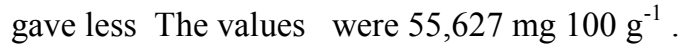

Effect of organic fertilizer levels and types of biofertilizer and their interactions for the two okra cultivars on the chlorophyll content of leaves $\left(\mathrm{mg} 100 \mathrm{gm}^{-1}\right)$. 
University of Thi-Qar Journal of agricultural research

ISSN Onlin:2708-9347, ISSN Print: 2708-9339 Volume 10, Issue 1 (2021) PP 54 - 69

https://jam.utq.edu.iq/index.php/main $\quad$ https://10.54174/UTJagr.Vo10.N1/06

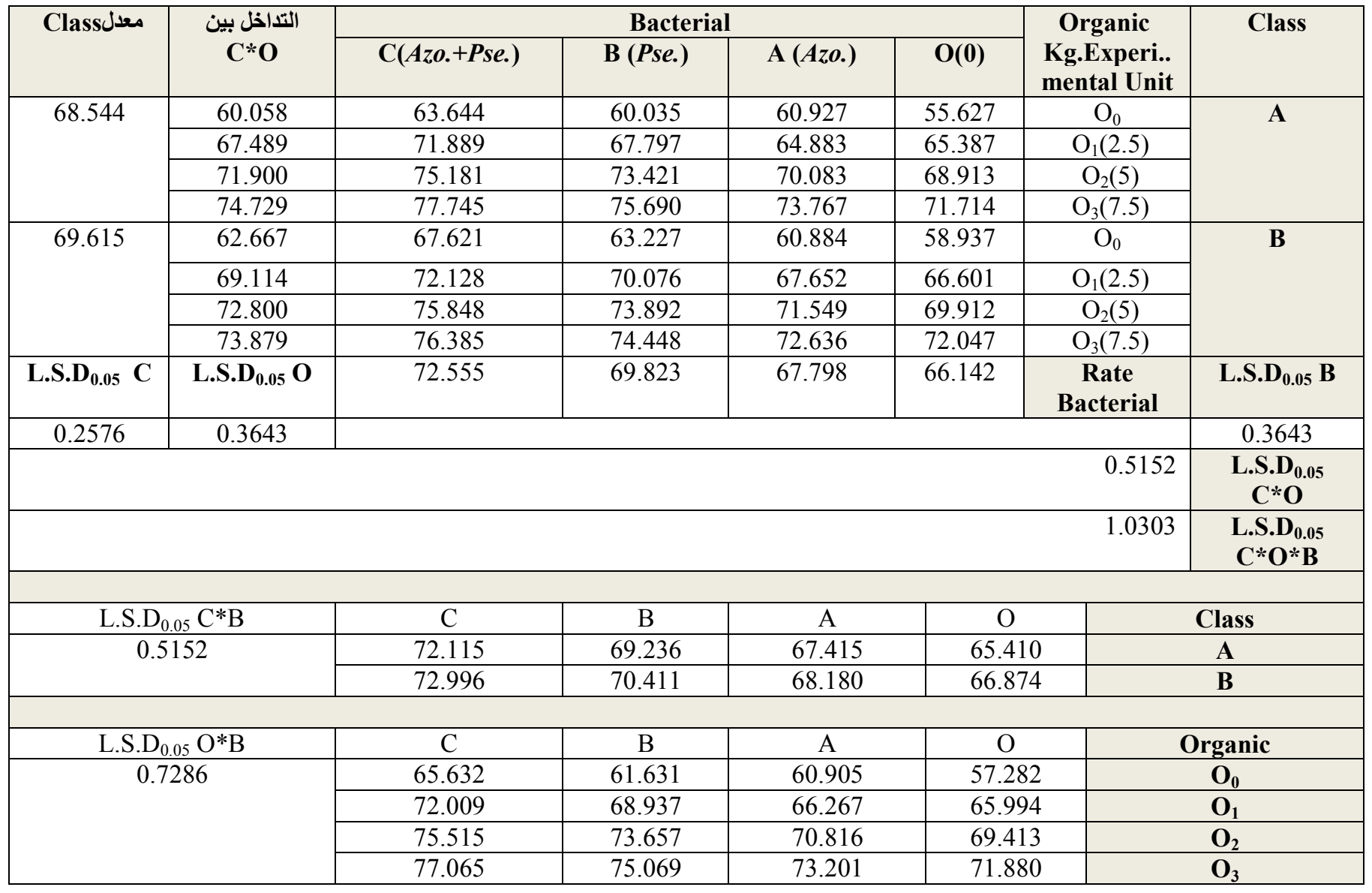

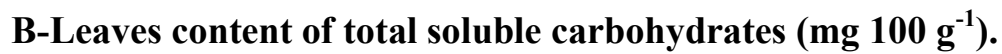

It was shown in Table (3) that the leaves content of total soluble carbohydrates was significantly superior to the Husseinawi okra variety A over the Petra okra variety B, with an increase of $1.111 \%$. The reason for this is due to the genetic variation between the cultivated varieties responsible for the chemical components of the plant, including carbohydrates (Mahdi, 2016). The same table showed that adding different levels of organic fertilizer had a significant effect on the amount of dissolved carbohydrates at levels $2.5,5$, and $7.5 \mathrm{~kg}$ experimental unit. The rates

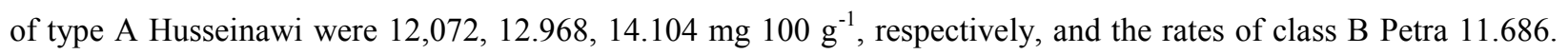

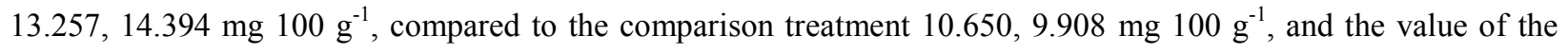
treatment increased by increasing the level of addition due to the role of the added organic matter in increasing the growth capacity of the roots and the absorption of nutrients, especially potassium, which is one of the important elements in Stimulating the photosynthesis process and the transfer of its products, as well as the formation of ATP responsible for filling the phloem tissue with the materials resulting from the photosynthesis process of carbohydrates and their transfer to the places they are stored in the fruits by the phloem (Viro, 1974). The 
nutritional status of the plant and the transfer of carbohydrates from the places of manufacture of leaves to the places of consumption of fruits to meet the requirements of growth, which leads to an increase in the content of these carbohydrates in accordance with Matto Link to it (Al-Ibrahimi, 2011) and (Nemati and Jaafar, 2013).The same table also showed that the addition of bio-fertilizers had a significant effect on the leaves' content of total soluble carbohydrates, as the treatment of the mixture of nitrogen-fixing and phosphorous-solvent bacteria $\mathrm{C}$ (Azo. + Pse.) outperformed, as it gave the highest rate of carbohydrate content of leaves, as it reached an average of $13.117 \mathrm{mg}$ $100 \mathrm{~g}^{-1}$ compared with the measurement treatment, which amounted to $10,683 \mathrm{mg} 100 \mathrm{~g}^{-1}$, due to the role of Azotobacter and phosphorous-dissolving bacteria in improving the dry matter characteristics of the plant and the carbohydrate content of leaves (Mahendran and Kumar, 1998), in addition to the role of added bacteria in Increasing vegetative growth, photosynthesis, and transportation of manufactured materials from places of manufacture to places of storage (Yazdani et al., 2009). The table also showed that the binary interaction between the cultivars and the organic fertilizers had a significant effect, as the treatment $\mathrm{O}_{3}$ of the class $\mathrm{B}$ gave the highest values amounted to $14.394 \mathrm{mg} 100 \mathrm{gm}^{-1}$, while the plants of the treatment $\mathrm{O}_{0}$ of the class $\mathrm{B}$ gave the lowest values of $9.908 \mathrm{mg} 100 \mathrm{gm}^{-1}$. The same table also shows that the bilateral interaction between cultivars and biofertilizers has a

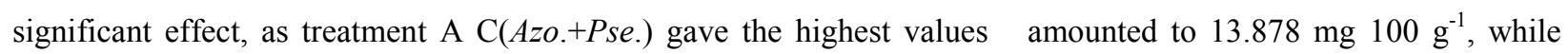
treatment plants $\mathrm{BO}_{0}$ gave the lowest values amounted to $10.670 \mathrm{mg} 100 \mathrm{~g}^{-1}$. The same table showed the bilateral interaction between organic and biofertilizers, which had a significant effect, as the treatment plants $\mathrm{O}_{3} \mathrm{C}($ Azo. $+P s e$. $)$

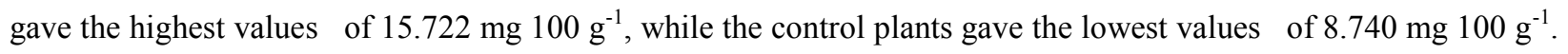
As for the triple interaction between the experimental factors, it was significant, as the interaction of the treatment plants $\mathrm{A}^{*} \mathrm{O}_{3}{ }^{*} \mathrm{C}($ Azo. + Pse. $)$ excelled in reaching the highest values, as it reached $15.740 \mathrm{mg} 100 \mathrm{gm}^{-1}$, while the plants of the treatment $\mathrm{B}^{*} \mathrm{O}_{0} * \mathrm{O}_{0}$ gave the lowest values. It reached $8.538 \mathrm{mg} 100 \mathrm{~g}^{-1}$.

Effect of organic fertilizer levels and types of biofertilizer and their interactions for the two okra cultivars on the total soluble carbohydrates content of leaves $\left(\mathrm{mg} 100 \mathrm{gm}^{-1}\right)$.

\begin{tabular}{|c|c|c|c|c|c|c|c|}
\hline \multirow[t]{2}{*}{ معدل Class } & \multirow{2}{*}{$\begin{array}{c}\text { التاخل بين } \\
\mathbf{C} \times \mathbf{O}\end{array}$} & \multicolumn{4}{|c|}{ Bacterial } & \multirow{2}{*}{$\begin{array}{c}\text { Organic } \\
\text { Kg.Experi.. } \\
\text { mental Unit }\end{array}$} & \multirow[t]{2}{*}{ Class } \\
\hline & & $\mathrm{C}($ Azo. + Pse. $)$ & $\mathrm{B}$ (Pse.) & $\mathrm{A}(A z o)$. & $\mathrm{O}(0)$ & & \\
\hline \multirow[t]{4}{*}{12.448} & 10.650 & 12.148 & 11.219 & 10.291 & 8.942 & $\mathrm{O}_{0}$ & \multirow[t]{4}{*}{ A } \\
\hline & 12.072 & 13.109 & 12.970 & 11.971 & 10.239 & $\mathrm{O}_{1}(2.5)$ & \\
\hline & 12.968 & 14.516 & 13.920 & 12.262 & 11.174 & $\mathrm{O}_{2}(5)$ & \\
\hline & 14.104 & 15.740 & 14.760 & 13.486 & 12.430 & $\mathrm{O}_{3}(7.5)$ & \\
\hline \multirow[t]{4}{*}{12.311} & 9.908 & 11.004 & 10.477 & 9.615 & 8.538 & $\mathrm{O}_{0}$ & \multirow[t]{4}{*}{ B } \\
\hline & 11.686 & 13.147 & 12.342 & 11.139 & 10.116 & $\mathrm{O}_{1}(2.5)$ & \\
\hline & 13.257 & 14.095 & 14.273 & 13.357 & 11.303 & $\mathrm{O}_{2}(5)$ & \\
\hline & 14.394 & 15.705 & 14.973 & 14.173 & 12.725 & $\mathrm{O}_{3}(7.5)$ & \\
\hline L.S.D ${ }_{0.05} \mathrm{C}$ & L.S.D $D_{0.05} \mathrm{O}$ & 13.683 & 13.117 & 12.037 & 10.683 & $\begin{array}{c}\text { Rate } \\
\text { Bacterial }\end{array}$ & L.S.D ${ }_{0.05} B$ \\
\hline 0.0399 & 0.0564 & & & & & & 0.0564 \\
\hline & & & & & 0.0798 & L.S.D & $\mathrm{C} * \mathrm{O}$ \\
\hline
\end{tabular}


University of Thi-Qar Journal of agricultural research

ISSN Onlin:2708-9347, ISSN Print: 2708-9339 Volume 10, Issue 1 (2021) PP 54 - 69

https://jam.utq.edu.iq/index.php/main $\quad$ https://10.54174/UTJagr.Vo10.N1/06

\begin{tabular}{|c|c|c|c|c|c|}
\hline & & & & 0.1597 & L.S.D $\mathrm{D}_{0.05} \mathrm{C}^{*} \mathrm{O} * \mathrm{~B}$ \\
\hline L.S.D $D_{0.05} \mathrm{C} * \mathrm{~B}$ & $\mathrm{C}$ & B & $\bar{A}$ & $\mathrm{O}$ & Class \\
\hline \multirow[t]{2}{*}{0.0798} & 13.878 & 13.217 & 12.002 & 10.696 & A \\
\hline & 13.488 & 13.016 & 12.071 & 10.670 & $\mathrm{~B}$ \\
\hline L.S.D ${ }_{0.05} \mathrm{O}^{*} \mathrm{~B}$ & $\mathrm{C}$ & B & $\mathrm{A}$ & $\mathrm{O}$ & Organic \\
\hline \multirow[t]{4}{*}{0.1129} & 11.576 & 10.848 & 9.953 & 8.740 & $\mathrm{O}_{0}$ \\
\hline & 13.128 & 12.656 & 11.555 & 10.177 & $\mathrm{O}_{1}$ \\
\hline & 14.305 & 14.096 & 12.809 & 11.238 & $\mathrm{O}_{2}$ \\
\hline & 15.722 & 14.866 & 13.830 & 12.577 & $\mathrm{O}_{3}$ \\
\hline
\end{tabular}

\section{C-The content of the leaves of carotene $\left(\mathrm{mg} 100 \mathrm{~g}^{-1}\right)$.}

The results of Table (4) show that there are significant differences between the cultivated cultivars in the leaf content of carotene, where the Petra okra cultivar B significantly outperformed the Husseinawi okra cultivar A significantly, with an average of $1.882,2.043 \mathrm{mg} 100 \mathrm{gm}^{-1}$, respectively, with a decrease of $8.55 \%$. The reason for this is due to the nature of the resulting genetic differences between the varieties and the impact of their response to this trait (Aktas et al., 2009). The same table showed that the addition of different levels of organic fertilizer had a significant effect on the amount of carotene at levels $2.5,5$, and $7.5 \mathrm{~kg}$ experimental unit, as the rates of class B Petra were 2.253, 1.585, $0.951 \mathrm{mg} 100 \mathrm{gm}^{-1}$, respectively, and the rates of class A Husseinawi reached 2.289, 1.736, $0.993 \mathrm{mg} 100 \mathrm{~g}^{-1}$ compared to the control treatment 2.738, $3.152 \mathrm{mg} 100 \mathrm{~g} \mathrm{~g}^{-1}$, and the amount of decrease increased by increasing the level of addition, for the organic matter to reduce the $\mathrm{pH}$ value and increase the availability of nutrients (Khalil, 2009). As well as increasing the vital activities that help cell division (Maheshbabu et al., 2008) and thus increase the products of carbon metabolism. The same table showed the effect of adding bio-fertilizer, which led to significant differences, where the percentage of decrease was superior to when treating the mixture (nitrogen-fixing bacteria and phosphorous-dissolving bacteria) reaching $0.974 \mathrm{mg} 100 \mathrm{~g}^{-1}$, compared to the comparison treatment $3.059 \mathrm{mg} 100 \mathrm{~g}^{-1}$, due to the reason for this To increase the absorption of phosphorous by the roots due to the phosphorous-dissolving microorganisms, which increases the density of the root system and its absorption, as well as providing the plant with its needs of water and other nutrients (Tisdale, 1997 and AlMandalawi, 2002), in addition to the contribution of phosphorous-dissolving bacteria to increase the plant's ability to increase the presence of phosphorus. Al-Karaki and Raddad, 1997, and (Govedarica et al., 1995) show that Azotobacter bacteria secrete growth regulators such as indole, gibberellin, phenol, which encourage vegetative and root growth from which it becomes able to absorb nutrients. Mohandes, 1987 and Bashir, 2004) showed that the combined addition of nitrogen-fixing and phosphorous-dissolving bacteria increases the concentration of phosphorous element.The table also showed that the bilateral interaction between the cultivars and the organic fertilizers had a significant effect, as the treatment $\mathrm{O}_{3}$ of the class $\mathrm{B}$ gave the highest decrease of $0.951 \mathrm{mg} 100 \mathrm{~g} \mathrm{~g}^{-1}$, 
while the plants of the treatment $\mathrm{O}_{0}$ of the class A gave the lowest decrease of $0.951 \mathrm{mg} 100 \mathrm{gm}^{-1}$. The same table also shows that the bilateral interaction between cultivars and biofertilizers had a significant effect, as treatment B C (Azo.+Pse.) gave the highest decrease of $0.762 \mathrm{mg} 100 \mathrm{~g}^{-1}$, while treatment plants $\mathrm{AO}_{0}$ gave the lowest decrease, amounting to $3.220 \mathrm{mg} 100 \mathrm{~g}^{-1}$. The same table showed the bilateral interaction between organic and biofertilizers, which had a significant effect, as the treatment plants $\mathrm{O}_{3} \mathrm{C}($ Azo. + Pse. $)$ gave the highest decrease, amounting to 0.297 $\mathrm{mg} 100 \mathrm{gm}^{-1}$, while the control plants gave the lowest decrease, amounting to $4.421 \mathrm{mg} 100 \mathrm{gm}^{-1}$. As for the triple interaction between the experimental factors, it was significant, as the interaction of the $\mathrm{B}^{*} \mathrm{O}_{3}{ }^{*} \mathrm{C}($ Azo. + Pse. $)$ overlap was superior in reaching the highest decrease, as it reached $0.211 \mathrm{mg} 100 \mathrm{~g}^{-1}$, while the plants of the treatment $\mathrm{A}^{*} \mathrm{O}_{0} * \mathrm{O}_{0}$ gave less The decrease amounted to $4.807 \mathrm{mg} 100 \mathrm{~g}^{-1}$.

Effect of organic fertilizer levels and types of biofertilizer and their interactions for the two okra cultivars on the carotene content of leaves (mg $\left.100 \mathrm{gm}^{-1}\right)$.

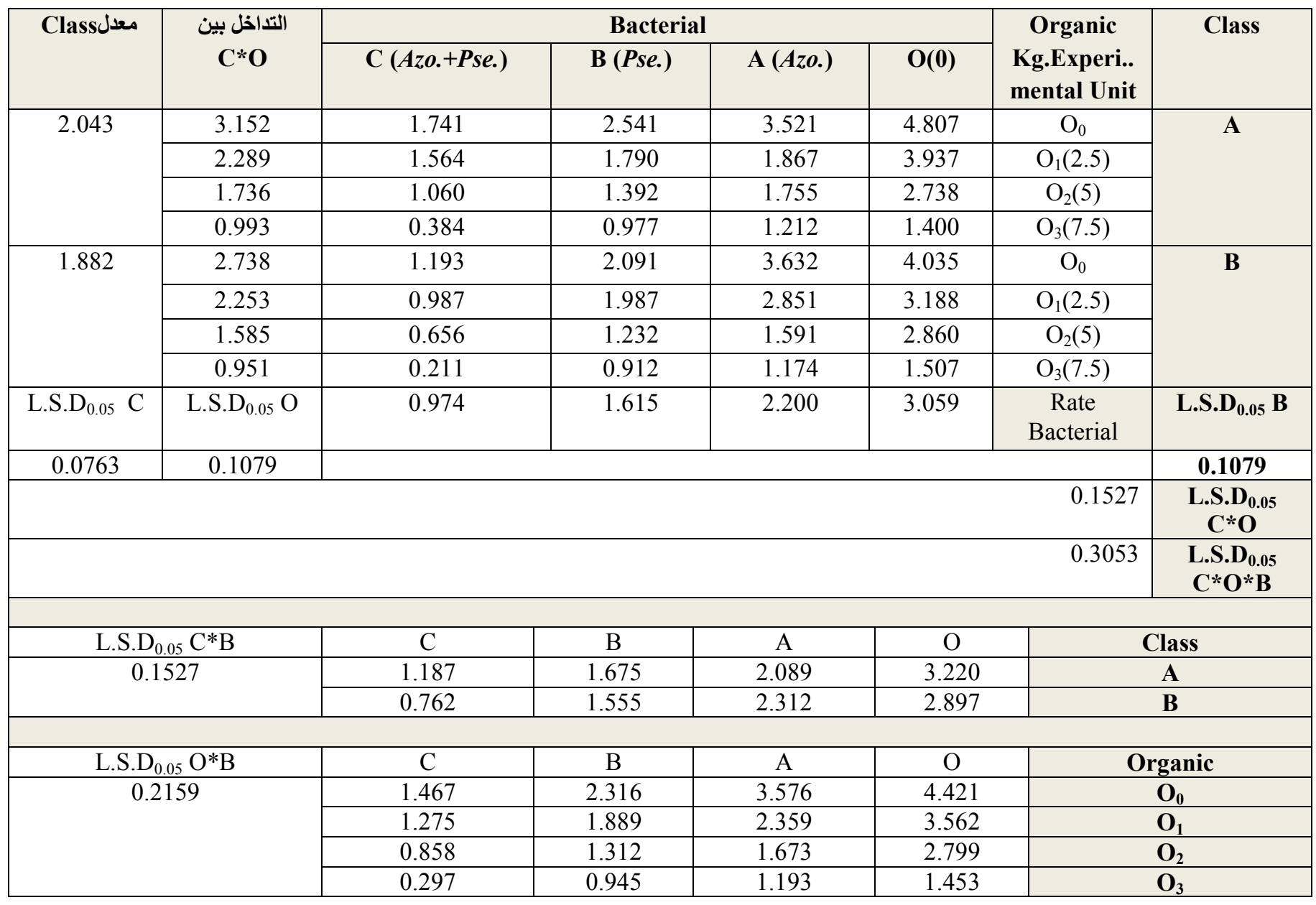




\section{D-Proline content in the leaves ( $\mu \mathrm{g}$ g-1).}

The results of Table (5) show that there are significant differences between the cultivated cultivars in the trait of proline in the leaves, where the Petra okra cultivar B significantly outperformed the Husseinawi plant cultivar A with a decrease.The reason for this is due to the nature of the resulting genetic differences between the varieties and the impact of their response to this trait (Aktas et al., 2009). The same table showed that adding different levels of organic fertilizer had a significant effect on the proline content at levels $2.5,5$, and $7.5 \mathrm{~kg}$ as an experimental unit. The rates of Petra B class were 200.2, 159.5, 142.9 micrograms $\mathrm{g}^{-1}$, respectively, and the rates of class A Husseinawi were $248.5,179.9,164.3 \mu \mathrm{g} \mathrm{g}^{-1}$ compared to the measurement treatment $257.5,248.4 \mu \mathrm{g} \mathrm{g}^{-1}$ for both cultivars and the amount of proline decreased with the increase in the level of addition, the external additions of organic fertilizers led to a decrease in the proportion of proline. Proline plays a role in the osmotic adjustment, which reduces the fertilizer concentration of proline as it works to reduce the tension on the plant. So that the rise in proline is a result of the osmotic effort of the cell tissue, which increases the absorption of water, because proline stores the metabolic materials in the cell and thus balances between the vacuole and the cytoplasm (Parson et al., 1979 and Hasegawa et al., 1984). The same table showed that the addition of biofertilizers had a significant effect on the significant decrease in the proline content in treatments $\mathrm{A}, \mathrm{B}$, and $\mathrm{C}$, the rates were $213.8,172.3,156.7 \mu \mathrm{g} \mathrm{g}^{-1}$ compared to no addition, which amounted to $257.8 \mu \mathrm{g} \mathrm{g}^{-1}$. As it works to dissolve insoluble phosphorous compounds, as well as its role in competition for adsorption sites, with high energy, this is consistent with (Bashir, 2004). The table also showed that the binary interaction between the cultivars and the organic fertilizers had a significant effect, as the treatment $\mathrm{O}_{3}$ of the $\mathrm{B}$ class gave the highest decrease in values amounting to $142.9 \mu \mathrm{g} \mathrm{g}^{-1}$, while the plants of the $\mathrm{O} 0$ treatment of the B class gave the lowest decrease in values amounting to $257.5 \mu \mathrm{g} \mathrm{g}^{-1}$. The same table also shows that the bilateral interaction between cultivars and biofertilizers had a significant effect, as the treatment $\mathrm{BC}($ Azo. + Pse. $)$ gave the highest decrease in values, amounting to $136.2 \mu \mathrm{g} \mathrm{g}^{-1}$, while the treatment plants $\mathrm{AO}_{0}$ gave the lowest decrease in values amounting to $259.8 \mu \mathrm{g} \mathrm{g}^{-1}$. The same table showed the bilateral interaction between organic and biofertilizers, which had a significant effect, as the treatment plants $\mathrm{O}_{3} \mathrm{C}($ Azo. + Pse. $)$ gave the highest decrease in values, amounting to $121.6 \mu \mathrm{g} \mathrm{g}^{-1}$, while the control plants gave the lowest values of $352.5 \mu \mathrm{g} \mathrm{g}^{-1}$. As for the triple interaction between the experimental factors, it was significant, as the overlapping treatment $\mathrm{A}^{*} \mathrm{O}_{3}{ }^{*} \mathrm{C}($ Azo. + Pse. $)$ excelled in reaching the highest decrease in values, as it reached $137.9 \mu \mathrm{g} \mathrm{g}^{-1}$, while the treatment plants $\mathrm{B}^{*} \mathrm{O}_{0} * \mathrm{O}_{0}$ gave less A decrease of 342.1 micrograms $\mathrm{g}^{-1}$. 
University of Thi-Qar Journal of agricultural research

ISSN Onlin:2708-9347, ISSN Print: 2708-9339 Volume 10, Issue 1 (2021) PP 54 - 69

https://jam.utq.edu.iq/index.php/main $\quad$ https://10.54174/UTJagr.Vo10.N1/06

Effect of organic fertilizer levels and types of biofertilizer and their interactions for the two okra cultivars on .(the leaf content of proline $\left(\mu \mathrm{g} \mathrm{g}^{-1}\right)$.

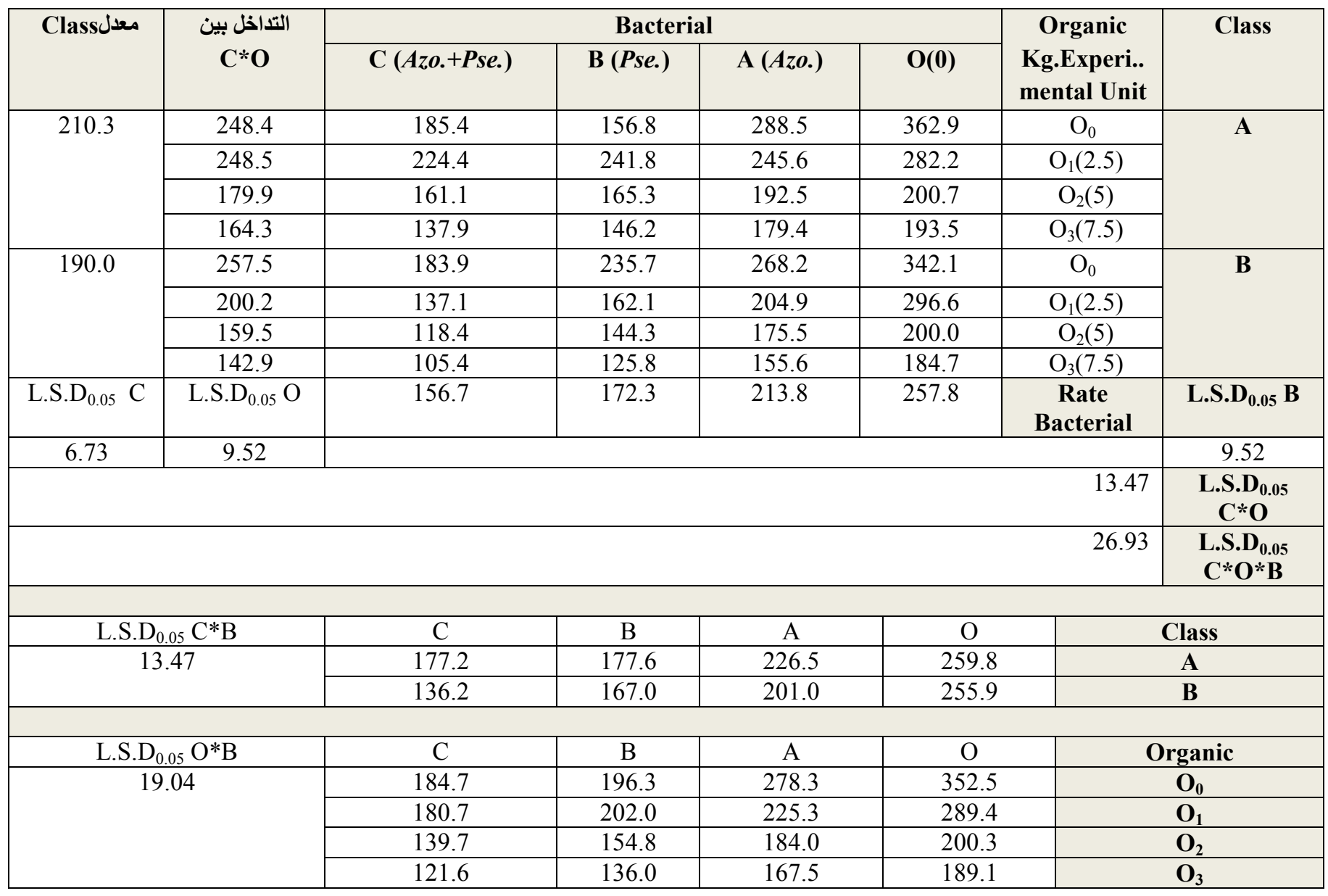

\section{E-Phenols in fruits $(\%)$.}

Table (6) shows that okra cultivars showed a significant increase in phenols in the fruits, where the A-Hussainawi cultivar outperformed the Petra B-cultivar with an increase of $4.36 \%$ for the ability of the Hussainawi cultivar to absorb nutrients from the soil more than it was in the Petra variety, and that the plant variety had an optional trait. And the genetic trait in absorbing the ready-made form of the element and its quantity from the medium (Abu Dahi and Younes 1988).The same table showed that the addition of different levels of organic fertilizers (2.5, 5, and 7.5 $\mathrm{kg}$ experimental units) had a significant effect on the phenols in the fruits, as the rates of the Husseinawi variety gave 1.942, 2.340, $2.742 \%$ compared to the treatment of no addition, which amounted to $1.505 \%$, and for the variety Petra okra 1.750, 2.182, $2.527 \%$ compared to the measurement treatment amounted to $1.711 \%$. The reason for the increase is that adding organic fertilizers to the soil works to increase the plant's absorption of nutrients, thus 
improving the photosynthesis process, thus increasing the accumulated manufactured materials inside the plant, which is reflected in the improvement Specific characteristics of the fruits (Yildirim, 2007).The same table showed that the addition of bio-fertilizers had a significant effect on this trait, as the rate of phenols in the fruits of the plant reached $1.969,2.214,2.534 \%$ and for the treatments (A, B, C) compared to the comparison treatment amounted to $1.632 \%$. Addition is due to the fact that the added microorganisms have better growth compared to not adding, thus it is characterized by obtaining an early crop with good quality characteristics. The nutritional status of the plant (Al-Samarrai, 2006) also found (Mahendran and Kumar, 1998) that the addition of Azotobacter and phosphorousdissolving bacteria improves the growth characteristics of plants. The table also showed that the binary interaction between the cultivars and the organic fertilizers had a significant effect, as the treatment $\mathrm{O}_{3}$ of the class $\mathrm{A}$ gave the highest values, amounting to $2.742 \%$, while the plants of the treatment $\mathrm{O}_{0}$ of the class $\mathrm{A}$ gave the lowest values, which amounted to $1.505 \%$. The same table also shows that the bilateral interaction between cultivars and biofertilizers has a significant effect, as the treatment $\mathrm{A} \mathrm{C}($ Azo. + Pse $)$ gave the highest values, amounting to $2.576 \%$, while the treatment plants $\mathrm{AO}_{0}$ gave the lowest values, which amounted to $1.615 \%$. The same table showed the bilateral interaction between organic and biofertilizers, which had a significant effect, as the treatment plants $\mathrm{O}_{3} \mathrm{C}$ (Azo.+Pse.) gave the highest values, which amounted to $3.408 \%$, while the comparison plants gave the lowest values, which amounted to $1.338 \%$. As for the triple interaction between the experimental factors, it was significant, as the overlapping treatment $\mathrm{A}^{*} \mathrm{O}_{3}{ }^{*} \mathrm{C}($ Azo. + Pse.) excelled in reaching the highest values, which amounted to $3.597 \%$, while the plants of the treatment $\mathrm{A}^{*} \mathrm{O}_{0} * \mathrm{O}_{0}$ gave the lowest values, which amounted to $1.321 \%$.

Table (6): Effect of organic fertilizer levels and types of biofertilizer and their interactions for the two okra cultivars .(\%) on phenols in fruits

\begin{tabular}{|c|c|c|c|c|c|c|c|}
\hline \multirow[t]{2}{*}{ معدلClass } & \multirow{2}{*}{ التداخل بين } & \multicolumn{4}{|c|}{ Bacterial } & \multirow{2}{*}{$\begin{array}{c}\text { Organic } \\
\text { Kg.Experi.. } \\
\text { mental Unit }\end{array}$} & \multirow[t]{2}{*}{ Class } \\
\hline & & $\mathrm{C}($ Azo. + Pse. $)$ & B (Pse.) & A (Azo.) & $\mathbf{O}(0)$ & & \\
\hline \multirow[t]{4}{*}{2.132} & 1.505 & 1.473 & 1.722 & 1.504 & 1.321 & $\mathrm{O}_{0}$ & \multirow[t]{4}{*}{$\overline{\mathbf{A}}$} \\
\hline & 1.942 & 2.330 & 2.101 & 1.840 & 1.498 & $\mathrm{O}_{1}(2.5)$ & \\
\hline & 2.340 & 2.902 & 2.529 & 2.256 & 1.672 & $\mathrm{O}_{2}(5)$ & \\
\hline & 2.742 & 3.597 & 2.933 & 2.467 & 1.970 & $\mathrm{O}_{3}(7.5)$ & \\
\hline \multirow[t]{4}{*}{2.043} & 1.711 & 2.125 & 1.790 & 1.573 & 1.355 & $\mathrm{O}_{0}$ & \multirow[t]{4}{*}{ B } \\
\hline & 1.750 & 1.964 & 1.827 & 1.703 & 1.505 & $\mathrm{O}_{1}(2.5)$ & \\
\hline & 2.182 & 2.660 & 2.121 & 2.138 & 1.809 & $\mathrm{O}_{2}(5)$ & \\
\hline & 2.527 & 3.218 & 2.690 & 2.275 & 1.927 & $\mathrm{O}_{3}(7.5)$ & \\
\hline L.S.D $0_{0.05} C$ & L.S.D $D_{0.05}$ O & 2.534 & 2.214 & 1.969 & 1.632 & $\begin{array}{c}\text { Rate } \\
\text { Bacterial }\end{array}$ & L.S.D D.05 $_{\text {B }}$ \\
\hline 0.0632 & 0.0893 & & & & & & 0.0893 \\
\hline & & & & & & 0.1263 & $\begin{array}{c}\text { L.S.D } \\
\quad C_{0.05} * \mathbf{O}\end{array}$ \\
\hline & & & & & & 0.2526 & L.S.D ${ }_{0.05}$ \\
\hline
\end{tabular}


University of Thi-Qar Journal of agricultural research

ISSN Onlin:2708-9347, ISSN Print: 2708-9339 Volume 10, Issue 1 (2021) PP 54 - 69

https://jam.utq.edu.iq/index.php/main $\quad$ https://10.54174/UTJagr.Vo10.N1/06

\begin{tabular}{|c|c|c|c|c|c|}
\hline & & & & & $C * O * B$ \\
\hline L.S.D ${ }_{0.05} C * B$ & $\mathrm{C}$ & $\mathrm{B}$ & A & $\mathrm{O}$ & Class \\
\hline \multirow[t]{2}{*}{0.1263} & 2.576 & 2.321 & 2.017 & 1.615 & $\mathbf{A}$ \\
\hline & 2.492 & 2.107 & 1.922 & 1.649 & B \\
\hline L.S.D ${ }_{0.05}$ O*B & $\mathrm{C}$ & B & $\mathrm{A}$ & $\mathrm{O}$ & Organic \\
\hline \multirow[t]{4}{*}{0.1786} & 1.799 & 1.756 & 1.539 & 1.338 & $\mathbf{O}_{0}$ \\
\hline & 2.147 & 1.964 & 1.772 & 1.501 & $\mathbf{O}_{1}$ \\
\hline & 2.781 & 2.325 & 2.197 & 1.740 & $\mathbf{O}_{2}$ \\
\hline & 3.408 & 2.811 & 2.371 & 1.949 & $\mathbf{O}_{3}$ \\
\hline
\end{tabular}

\section{CONCLUSIONS.}

The results of the study confirmed the importance of organic fertilizer and types of biofertilizer for the production of okra varieties within the farming systems, and from this we conclude the following:

1- The Husseinawi variety of good quality and quantity can be adopted.

2- The fourth level of organic fertilizer $\left(\mathrm{O}_{3}(7.5 \mathrm{~kg}\right.$ experimental unit $\left.)\right)$ can be adopted in the characteristics of vegetative growth, chemical content of leaves, flowering and production characteristics, and qualitative characteristics of fruits.

3- The fourth level of bio-fertilizer $(\mathrm{C}($ Azo. + Pse. $))$ can be adopted, a mixture of Azotobacter and Pseudomonas bacteria in the characteristics of vegetative growth, the content of the leaves of chemicals, the characteristics of flowering and production, and the qualitative characteristics of the fruits.

\section{CONCLUSION}

Based on the results of the study, we recommend the following:

1- Conducting more studies on other varieties suitable for cultivation under greenhouse conditions.

2- The use of organic matter at the level of (o3) $7.5 \mathrm{~kg}$ of different experimental units to improve the physical and chemical properties of the soil, as it is positively reflected on the yield, both quantitative and qualitative.

3- Increasing the farmer's awareness of the use of bio-fertilizer (C(Pse.+Azo.) because it provided the necessary elements and the appropriate nutritional needs for the okra plant, and because of its positive effects, so it is preferable to apply it in various vegetable crops. 
4- A study of organic agriculture for the economic feasibility of various organic vegetable crops compared to the cultivated vegetable crops resulting from traditional agriculture.

\section{REFERENCES.}

1. Abd El-Kader, A.A.;Saaban, S.M. and Abd El-Fattah, M.S.(2010). Effect of irrigation levels and organic compost on okra plant (Abelmoshus esulentus L.) grown in sandy calcareous soil. Agriculture and Biology Journal of North America, 1:225-231.

2. Abou-Hussein, S.D., I. EL-Oksh, T. E-Shorbagy and M. Gomaa. (2002). Efect of cattle manure, bio-fertilizers and reducing mineral fertilizer on nutrient content and yield of potato plant. Egypt. J.Hort. 29 (1): 99-115.

3. Abu Dahi, Youssef Muhammad and supporter Ahmed Al-Younis. (1988). Plant Nutrition Guide. Baghdad University. Ministry of Higher Education and Scientific Research.

4. Aktas , H., K. Abak, and S. Sensoy.(2009) . Genetic diversity in some Turkish pepper (Capsicum annuum L.) genotypes revealed by AFLP analyses.African J. Biotech. 8(18): 4378-4386.

5. Al-Amri, Nabil Jawad Kazim. (2011). Response of tomatoes grown under greenhouse conditions to organic and biological fertilizers. PhD thesis. Department of horticulture and garden engineering. faculty of Agriculture . Baghdad University . Ministry of Higher Education and Scientific Research. The Republic of Iraq .

6. Al-Haddad, Muhammad Al-Sayyid Mustafa. (1998). The role of bio-fertilizers in reducing agricultural costs, reducing environmental pollution and increasing crop productivity. faculty of Agriculture. Ain Shams University. The national training course on the production of biofertilizers. The Hashemite Kingdom of Jordan 16-21/5/1998.

7. Al-Ibrahimi, Abdel-Gawad Abdel-Zahra Kitaf (2011). Effect of the type of organic waste and spraying with boron and sugar solution on the growth and yield of pepper. Capsicum annuum L. grown in greenhouses. Master's Thesis . faculty of Agriculture . University of Kufa .

8. Al-Jubouri, Soraya Khalaf Badawi. (2013). Effect of different levels of Trichoderma Harzianum biofertilizer on some parameters and thermodynamics of potassium. Diyala Journal of Agricultural Sciences. 544533:(2)5.

9. Al-Karaki, G.N.; A.Al-Raddad and R.B. Clarck .( 1998). Water stress and mycorrhizal isolate effects of wheat. J. of Plant Nutrition U.S.A 211(5): 891-902.

10. Al-Mandalawi, Donia Hussein Wali. (2002). Effect of adding mixed fertilizer $(\mathrm{K}+\mathrm{P})$ by soil and spraying on growth and components of tomato plant grown in heated greenhouses. Master Thesis. faculty of Agriculture. Baghdad University.

11. Al-Samarrai, Ismail Khalil. (2006). Interaction between Mycorrhizal fungi and Trichoderma and their effect on spore formation in soil planted with Mycorrhizal plants. Iraqi Agriculture Journal. Volume (11), issue (2). 
12. Alshamri, Aziz Mahdi Abd and Omar Ghazi Saud. (2014). Effect of spraying with some organic nutrients and soil method on yield of three huds of cucumber under protected cultivation conditions. Diyala Journal of Agricultural Sciences. 6(2): 60-73.

13. Bashir, Afra Younis. (2004). Interaction between Mycorrhizal and Azotobacter zoospermum and its effect on the growth and yield of wheat. PhD thesis, College of Agriculture, University of Baghdad.

14. Boras, Mitadi, Bassam Abu Turab and Ibrahim Al-Basit. (2011). Production of vegetable crops. Theoretical part. Faculty of Agriculture - Damascus University. 455.

15. Cresser, M. S. and J. W. Parsons .(1979). Sulphuric-perchloric acid of digestion of plant material for determination of nitrogen, phosphorus,potassium, calcium and magnesium. Analytical Chimica Acta, 109:431-436.

16. D. Sathish Kumar, D. Eswar Tony, A. Praveen Kumar, K. Ashok Kumar, Bramha Srinivasa Rao, Ramarao Nadendla. (2013). Areview on: Abelmoschu esculentus (Okra). International research Journal of Pharmaceutical and Applied Science (IRJPAS). Int Res. J. Pharm. App Sci., 2013; 3 (4): 129- 132.

17. Farida, H.B., M.M. El-Dsouky, H.S. Sadiek and A.A. Abo-Baker (2003). Response of tomato to inoculation with oculants of Different bacterial species. Assiut J. Agric. Sci. 345): 275-285.

18. Ghoname, A. and M.R. Shafeek. (2005).Growth and productivity of sweet pepper (Capsicum annuum L.) Grown in plasticHouse as affected by organic mineral and Bio- N-fertilizers. Agronomy.J. 4 (4): 369-372.

19. Govedarica, M.; V. Milic and D.J. Grozdenovic .1993. Efficiency of the association between Azotobacter chroococcum and some tomato varieties. Zemljiste-i-biljka (Yugoslavia)42 (2):113-120.

20. Hasegawa, P. M., Bressan, R. A., Handa,S. and Handa, A. K.(1984). Cellular mechanisms of tolerance to water stress. Hort. Sci., 19: 371-377.

21. Khalil, Shakir Khalil. (2009). The effect of agricultural media and the location of the side branch on the growth and yield of tomato. Master Thesis. Technical College - Musayyib. Babylon. Iraq.

Mahdi, Shaima Sabah (2016). Studying the genetic diversity of different varieties of Capsicum annuum L. .i for samples from local markets using some molecular genetic techniques. PhD thesis - College of

Education for Pure Sciences - Ibn Al-Haytham - University of Baghdad

22. Mahendran, P.P. and N. Kumar .(1998).Effect of biofertilizers on tuber yield and certain quality parameters of potato. South Indiaqn Horticulture, 46(1-2): 47- 48.

23. Mahendran, P.P. and N. Kumar .1998.Effect of biofertilizers on tuber yield and certain quality parameters of potato. South Indiaqn Horticulture, 46(1-2): 47- 48.

24. Maheshbabu, R. H., Patil, N. K. B. and Babalad , H. B. (2008).Effect of organic manures on plant growth, seed yield and quality of soybean. Karnataka J. Agric. Sci.,21( 2) : 219-221.

25. Mohandes, S. .(1987). Field response of tomato (Lycopersicon esculentum) to inoculation with a VA mycorrhizal fungus Glomus Fasiculatum and with Azotobacter vinelandii. Plant and Soil., 98: 295-297. 
26. Mostafa, M.M, . 2002. Effet of bio-fertilizer and magnetic technique onThe growth of some annual plants. Alex. J. Agric. 47(2): 151-162.

27. Nemati, and Z.E. Jaafer . (2013). Effect of compost antioxidant components and fruit quality of sweet pepper (capsicum annuum L.) . Journal of Central European Agriculture, (2013), 14(2), p.47-56 .

28. Peter, M.B and Carl, R.J.(2005). Nutrient cycling and maintaining soil fertility in fruit and vegetable crop systems., Dep. Soi. W .Clim. M., P:1193.

29. Qurbanly, M. , Hashemyfar S. and Fallah A. .(2006). The interaction of irrigation and nitrogen on some morphological and physiological traits of rice plants (Oryza sativa L.). Journal of Agricultural Science 12:415428.

30. Tisdale, S.L., W.L. Nelson, J.D. Beaton and J.L. Harllin .(1997). Soil fertility and fertilizers. Prentice. Hall of India, New Delhi.

31. Verma, R., Maurya, B. R., Meena, V .S.,Dotaniya, M. L., Deewan, P., andJajoria, M. (2017). Enhancing production potential of cabbage and improves soil fertility ststus of Indo-Gangetic Plain through application of bio-organics and mineral fertilizer Int. J .Curr Microbiol App.Sci,6(3):301-309.

32. Viro, M. (1974). The effect of minerals in nutrition with Potassium on the translocation assimilates and citation ( Lycopersicon esculentum ).Diss fachbereich Ernahrungs wissenschaften Justus, liebig universitat Giessen.

33. Yazdani, M.; M. K. Bahmanyar ; H .Pirdashti; M.A. Esmaile .(2009). Etfect of phosphate solubilization microorganism (PSM) and plant growth promotion rhizobacteria (PGPR) on yield componenets of corn (Zea mays L.) World Academy of Science,Engineering and Technology.37:90-92.

34. Yildirim, E. (2007). Foliar and soil fertilization of humic acid affect productivity and quality of tomato. Acta Agriculturae Scandinavica Section B-Soil and Plant Science, 57(2). 182-186. 